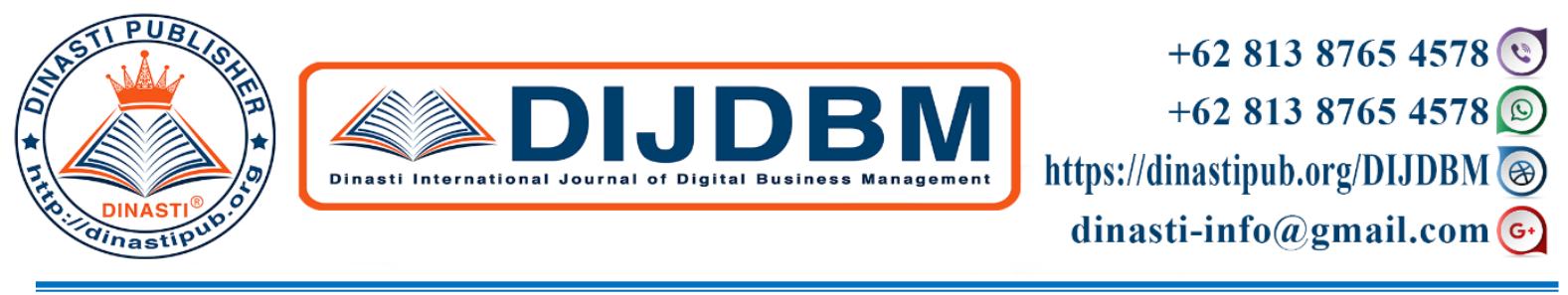

\title{
THE FACTOR WHICH INFLUENCE IT INFRASTRUCTURE: SOFTWARE, IT FLEXIBILITY AND ORGANIZATIONAL PERFORMANCE (STUDY OF MANAGEMENT INFORMATIONS SYSTEMS LITERATURE)
}

\section{Hazimi Bimaruci Hazrati Havidz ${ }^{1)}$, M. Rizky Mahaputra ${ }^{2)}$}

${ }^{1)} \mathrm{Ph} . \mathrm{D}$ Student, Wuhan University of Technology, 205 Luoshi road, Wuhan, Hbei, China.

${ }^{2)}$ Magister Management Program, Universitas Mercu Buana, Jakarta, Indonesia

\begin{tabular}{|c|l|}
\hline $\begin{array}{c}\text { ARTICLE INFORMATION } \\
\text { Received: 25 August 2020 } \\
\text { Revised: 15 October 2020 } \\
\text { Issued: 29 November 2020 }\end{array}$ & $\begin{array}{l}\text { Abstract: This article discusses literature review } \\
\text { studies of Business Information Systems, analyzing } \\
\text { factors that affect IT infrastructure: Software, IT } \\
\text { Flexibility and Organizational Performance. The } \\
\text { method of writing this article is literature study or } \\
\text { library research. The results are that: 1) Software has a } \\
\text { relationship and affects the IT infrastructure; 2) IT } \\
\text { Mahaputra } \\
\text { E-mail: }\end{array}$ \\
$\begin{array}{l}\text { hazimi.bimaruci@gmail.com } \\
\text { flexkymahaputra55@gmail.com } \\
\text { infrastructure; and 3) Organizational performance has } \\
\text { a relationship and affects the IT infrastructure. }\end{array}$ \\
Keywords: Software, IT Flexibility, Organizational \\
Performance
\end{tabular}

\section{INTRODUCTION}

In today's digital era, information technology is very advanced, it can be felt and seen from the changes in natural resources into various kinds of tools. Along with its development, information technology has emerged very clearly, such as what we use every day for cellphones, computers, laptops, machines, motorbikes, cars, and many more. With the capability of Information Technology, an organization is created that effectively and efficiently utilizes Information Technology Resources to improve its Organizational Performance (Boudreau, 2008). In addition, IT infrastructure is also the capability of Information Technology in organizations (Bharadwaj, 2000).

Information technology infrastructure is a long-term asset, long-term value from shareholders and represents the long-term choice of an organization (Halim, 2015). Because 
this is a long term, it must be managed properly. This management can be done in accordance with applicable standards, because this is very important for an organization. In this management there are often problems in funding, therefore funding / finance is a factor that affects the sustainability of IT infrastructure. If this funding is properly managed by an organization, this IT infrastructure can develop effectively and efficiently. On this basis, IT infrastructure development requires funds / finance, (Ali H. d., 2010).

The development of IT infrastructure will be able to develop with good programs, so that it can influence technological changes in the organization by means of the flexibility of Information Technology. The flexibility of the IT infrastructure is an important part of the organization to minimize the risks that occur (Isdianto, 2014). Meanwhile, IT infrastructure can be implemented using a strategic plan from an information technology that is tailored to the plans of the organization. That's why the company must improve the performance of the organization so that it can take advantage of this IT infrastructure properly.

Based on the empirical experience of many young students and lecturers as well as other researchers, it is difficult to find supporting articles in research as previous research or as relevant research. Articles as relevant researchers are needed to strengthen the theory under study, to see the relationship between variables and to build hypotheses, are also indispensable in the discussion of research results.

This article specifically discusses Finance, IT Flexibility, and Organizational Performance that affect Information Technology Infrastructure, (A Study of Management Information Systems Literature). Of course not all of the factors that affect the Information Technology Infrastructure in this article, only a small part will be reviewed and reviewed.

Based on the background of the problem above, the problem formulation of this article is to review the theory of the influence of the independent variable on the dependent variable as shown below:

1) Does the software have a relationship and affect the IT infrastructure.

2) Does IT flexibility have a relationship and influence on IT infrastructure.

3) Does Organizational Performance have a relationship and influence on IT Infrastructure.

\section{THEORITICAL REVIEW}

\section{Management Information System (MIS)}

The definition of a Management Information System (MIS) is an information system designed to support information needed for decision making by the Manager, Ali, H. (2010).

Information systems make full use of IT (information technology) and are synonymous with computerized and automation systems. SI consists of hardware, software, database, communication, brainware and management components. In detail, information resources will be discussed in part two of TI, Ali, H. (2010). 
Leaders, managers or staff in an organization or institution will be able to carry out their duties and functions effectively and efficiently if they are able to empower all available resources. The available resources are: man, money, machine, method, information technology and other resources such as markets and materials, Ali, H. (2010).

The purpose of applying SIM in particular is to convey information to managers / leaders about the performance of the organization and its environment in the past, present and forecasts in the future, Ali, H., \& Wangdra, T. (2010).

\section{Information Technology Infrastructure}

Kegiatan masyarakat yang menekankan inefisiensi dari aktivitas organisasinya dengan the structure used to support this with a physical form is also called infrastructure (Sekarsari, 2019). In the organization Information Technology is one of the important resources to excel in its competition in the current era of globalization (Ali H., 2009). Information Technology (IT) infrastructure is an investment in hardware, software, and services such as consulting, education and training that are shared across companies or all business units in the company (Laudon, 2010). In the IT field, it includes hardware such as mainframe computers, servers, laptops, and PDAs, while software such as operating systems and applications that have many functions, besides that, there is also a database to store important data (Reynolds, 2010).

Important factors possessed by IT Infrastructure are the implementation of Network Systems, Multiplatforms Interface, Database Management Systems, Virtual Server, and so on (Antoni, 2016).

So it can be concluded from some of the above theories that Information Technology Infrastructure is a foundation or framework that supports a system or organization that is spread across several data centers controlled by an organization.

\section{Software}

Another name for software is also called software. Like other names, namely software, its nature is different from hardware or hardware, if hardware is a real component that can be seen and touched by humans, then the software or software cannot be touched and seen physically, the software is not visible. physically and intangible objects but we can operate it, through this software or software a computer can run a command.

Software, also called software, is a collection of several commands executed by a computer machine in carrying out its work. This software is a record for computer machines to store orders, as well as other documents and archives.

Software can be broadly divided into 3 parts. The following is a discussion of the types of software:

- Operating System ( OS ).

- Application.

- Programming Language. 
The development of information technology is very fast, the increasingly complex structures and business competition (global competition, development of marketing strategies) encourage companies to make technological changes to help company operations, increase effectiveness and service because companies will experience many obstacles if they continue to use conventional methods, (Khakim, KN, \& HADIPRAJITNO, B. 2011).

\section{Information Technology Flexibility}

Flexibility is the ability of an organization to respond to or respond to environmental changes, both internal and external (Arafat, 2016). This environmental change can be used for new opportunities in both small and large organizations so that they can overcome the size of the organization (Gaol, 2008). Information Technology flexibility is the readiness and ability of IT infrastructure to easily deploy or support the available hardware, software, communication technology, data and so on to commit to both physical and personnel technical components (Byrd, 2000).

The flexibility of information technology is very important to support the process of employee performance on infrastructure (Tjahyawati A., 2012). The innovations in information technology make employees develop in the face of changes in information technology. Flexibility, efficiency and reliability are IT transformations that include the use of their services (Laudon, 2010). These flexibility characteristics are Compatibility, Connectivity, Modularity, and Flexible IT Personnel (Ness, 2005).

So it can be concluded that IT flexibility can affect operational efficiency and effectiveness for information technology in a particular organization or company.

\section{Organizational Performance}

Performance is the result that is achieved because they are motivated by work and satisfied with the work they are doing (Aima, 2017). Performance is a reflection of achieving measurable quantity and quality of work produced by individuals, groups and organizations (Anshori, 2015). The results can be measured by providing feedback based on standard measures of quality and quality on the performance of the organization (Kumaat, 2015). Increasing performance is carried out in an organization that aims to achieve the target of the organization.

The definition of organizational performance itself is the accumulative result of all work activities within the company (Robbins, 2010). Organizational performance is an influence on information technology (Widuri, 2013). Organizational performance is something that has been achieved by the organization within a certain period of time, whether related to input, output, outcome, benefit, or impact (Sobandi, 2006). Of course, the work achieved by this organizational performance is full of responsibility for achieving an effective and efficient performance improvement.

So it can be concluded that in meeting the daily customer needs of an organization, organizational performance is very influential in this case for the better. 


\section{RESEARCH METHODS}

The method of writing scientific articles uses qualitative methods and literature studies or Library Research. Review books and journals in accordance with the theory discussed, especially in the scope of Management Information Systems (SIM). Qualitative research should be used inductively and consistently according to methodological assumptions that do not lead to questions. Conducting qualitative research is exploratory in nature (Ali $\mathrm{H}$. d., 2013).

Furthermore, it is discussed with a section entitled Review of Literature, research that studies or critically reviews academic-oriented knowledge, ideas, or findings and can make comparisons with the results (Ali H. d., 2013).

\section{RESULTS AND DISCUSSION}

\section{The relationship or influence between exogenous variables and endogenous variables}

This article analyzes and discusses the variables of Information Technology Infrastructure, namely Finance, IT Flexibility, and Organizational Performance.

\section{Influence or relationship between software variables and IT infrastructure.}

Software has an effect on Information Technology Infrastructure, this statement is based on articles from relevant research and reviews, including: (Khakim, K. N., \& Hadiprajitno, B. 2011), (Darius Antoni, D. A., \& Fatoni, F. 2016), (Noviari, 2007), (Forda, 2013), (Fitriawati, 2017), dan (Widajanti, 2011).

\section{Influence or variable relationship between IT flexibility and IT infrastructure.}

Flexibility affects Information Technology Infrastructure, this statement is based on articles from relevant and reviewed research, including: (Kartika, 2015), (Tjahyawati A., 2012), dan (Suryani, 2013).

Flexibility gives the organization the ability to control the environment outside the organization effectively which is a potential source for achieving a good competitive position. Meanwhile, according to (Akintoye, 2012) this infrastructure is more referred to as hard / physical Information Technology assets and software that provide a technological foundation for present and future business application organizations.

The flexibility of this technology infrastructure has the competence required by the owner of an organization in obtaining good performance. Infrastructure flexibility also determines the company's ability to quickly respond to changes from outside, which is very important to generate innovation. Because infrastructure is flexible, infrastructure is also the foundation of strength that will determine the application system to be built by an organization.

Based on the description above, it can be concluded that IT flexibility has an effect on new IT infrastructure innovations, so that this flexibility needs to be evaluated and improved again in IT infrastructure development. 
The influence or relationship of the organizational performance variable on IT infrastructure.

Organizational performance affects Information Technology Infrastructure, this statement is based on articles from relevant and reviewed research, including: (Anggraini, 2013), (Iranto, 2012), (Djatikusumo, 2016), and (Rahayu, 2020).

One of the causes of inconsistent IT Infrastructure results is the difference in measuring tools used to measure organizational performance. But the Information Technology Infrastructure becomes the main source of business and the key source for competitive advantage in any organization (Iranto, 2012). The availability of information technology infrastructure in an organizational environment will have an advantage in increasing the provision of information on the management decision-making process for organizational performance.

Organizational performance is very influential with Information Technology Infrastructure, which is marked by the longer the IT infrastructure is getting more advanced. So that Organizational Performance has a positive influence on Information Technology Infrastructure.

\section{Conceptual Framework}

Based on theoretical studies and scientific article reviews, the conceptual framework for this literature review is:

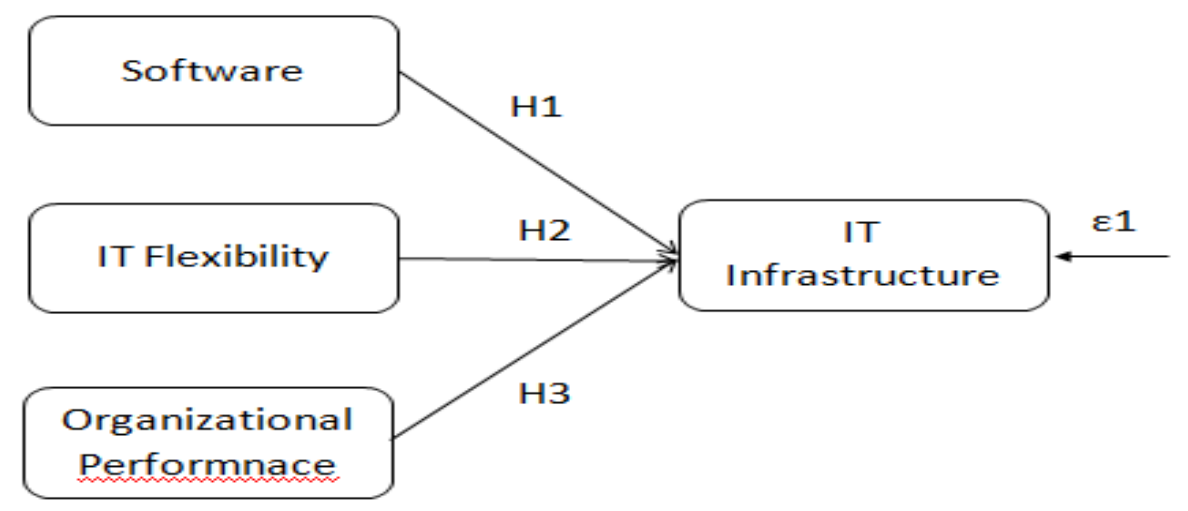

Figure 1: Conceptual Framework

Based on theoretical studies, review of research results from relevant journals and images from the conceptual framework, then 1) Software has an effect on IT infrastructure; 2) IT flexibility affects IT infrastructure and 3) Organizational performance affects IT infrastructure.

\section{CONCLUSIONS AND SUGGESTIONS}

\section{Conclusion}

Based on the discussion, it can be concluded to build a hypothesis for further research as below:

1) Software is related to and influence IT infrastructure. 
2) IT flexibility relates to and affects IT infrastructure.

3) Organizational performance affects and relates to IT infrastructure.

\section{Suggestion}

Based on the above conclusions, the suggestion in this article is that there are still many other factors that affect IT infrastructure, therefore further studies are needed to complete what other factors can affect IT infrastructure, such as hardware, databases, applications, information systems and so on.

\section{References}

Aima, H. R. (2017). Model of Employee Performance: Competence Analysis and Motivation *Case Study at PT. Bank Bukopin, Tbk Center). Journal of Research in Business and Management, 49-59.

Akintoye, A. ,. (2012). Construction Innovation and Process Improvement. West Sussex: Wiley-Blackwell.

Ali, H. (2009). Sistem Informasi Manajemen, Berbasis Teknologi Informasi. Jogyakarta: Hasta Cipta Mandiri.

Ali, H. d. (2010). Technopreneurship Dalam Perspektif Bisnis Online. Baduose Media.

Ali, H. d. (2013). Metode Penelitian (Petunjuk Praktis untuk Pemecahan Masalah Bisnis, Penyusunan Skripsi, Tesis, dan Disertasi).

Anggraini, N. D. (2013). Pengaruh Praktek Knowledge Management Terhadap Kinerja Organisasi (Studi Empiris pada Satuan Kerja Perangkat Daerah Kota Salatiga). Semarang: Repository Universitas Diponegoro.

Anshori, M. Y. (2015). Pengaruh Orientasi Pasar, Intellectual Capital, dan Orientasi Pembelajaran Terhadap Inovasi Studi Kasus Pada Industri Hotel di Jawa Timur. International Research Journal Of Business Studies.

Antoni, D. d. (2016, September). Faktor-Faktor Infrastruktur Teknologi Informasi Corporate di Kota Palembang. Jurnal SISFOKOM, 05, 38.

Arafat, Y. (2016). Fleksibilitas SIstem Informasi dari Perspektif Pengguna dan Pengembang Sistem Informasi. Jurnal ELKHA, 37-41.

Bharadwaj, A. S. (2000). A Resource-Based Perspective on Information Technology Capability and Firm Performance: An Empirical Investigation. MIS Quartely, 169196.

Boudreau, M. ,. (2008). Green IS: Building sustainable business practices. Information Systems. 
Byrd, T. d. (2000). An Exploratory Analysis Of The Information Technology Infrastructure Flexibility Countruct. Journal Of Management Information System, 167-208.

Djatikusumo, K. N. (2016). Pengaruh Penggunaan Teknologi Informasi dan Komputer terhadap Kinerja Organisasi (Studi Kasus di UMKM Kota Malang). Industrial Research Workshop and National Seminar, 66-71.

Fitriawati, M. (2017). Perkembangan Infrastruktur Teknologi Informasi dari Evolusi Infrastruktur. Jurnal Teknologi dan Informasi, 78-87.

Forda, G. (2013). Perancangan Infrastruktur Teknologi Informasi Adaptif Pada Universitas Lampung. Jakarta: Library Universitas Indonesia.

Gaol, C. J. (2008). Sistem Informasi Manajemen: Pemahaman dan Aplikasi. PT Grasindo.

Halim, E. d. (2015). Evaluasi TataKelola Infrastruktur TI dengan Framework COBIT 5 (Studi kasus: STMIK-STIE Mikroskil). Jurnal Sistem Informasi, 74-82.

Iranto, B. D. (2012). Pengaruh Kepuasan Pengguna Sistem Informasi Terhadap Kinerja Individu (Studi pada PT. PLM (PERSERO) Distribusi Jawa Tengah dan DIY). Semarang: Repository Universitas DIponegoro.

Isdianto, H. (2014). Perencanaan Infrastruktur Teknologi Informasi yang Adaptif untuk Menopang Perubahan Paket Aplikasi: Studi Kasus Bank XYZ. Jakarta: Universitas Indonesia.

Kartika, M. (2015). Pengaruh Fleksibilitas Infrastruktur Teknologi Informasi dan Pelayanan Publik Terhadap Implementasi Aplikasi E-SPT(Survey Pada Kantor Pelayanan Pajak Madya Bandung). Bandung: Unikom Repository.

Kumaat, R. d. (2015). Pengaruh Pendidikan, Pelatihan, dan Inovasi Terhadap Kinerja Pegawai Badan Pelaksana Penyuluhan dan Ketahanan Pangan Kota Manado. Jurnal Riset Ekonomi, Manajemen, Bisnis dan Akuntansi.

Laudon, K. C. (2010). Sistem Informasi Manajemen. Jakarta Selatan: Salemba Empat.

Maisharoh, T. d. (2020). Financial Statements Analysis in Measuring Financial Performance of the PT. Mayora Indah Tbk, Period 2014-2018. Journal of Contemporary Information Technology, Management, and Accounting, 63-71.

Ness, L. R. (2005). Assesing The Relationship Among IT Flexibility, Strategic Aligment, and IT Effectiveness(Studi overview and findings). journal of Information Techology Management, 1-17.

Noviari, N. (2007). Pengaruh Kemajuan Teknologi Informasi Terhadap Perkembangan Akuntansi. Jurnal Ilmiah Akuntansi dan Bisnis, 1-14. 
Rachmat. (2020). Keuangan. Retrieved from Wikipedia: https://id.m.wikipedia.org/wiki/keuangan

Rahayu , R. ,. (2020). Kapabilitas Teknologi Informasi, Kinerja Perusahaan, dan Nilai Perusahaan. Jurnal Riset Akuntansi Terpadu, 54-66.

Reynolds, G. W. (2010). Principles of Information System: A Managerial Approach. Yogyakarta: Course Technology.

Robbins, S. a. (2010). Manajemen. Jakarta: Erlangga.

Sekarsari, N. (2019). ICT dan Kinerja Organisasi: Peran Mediasi Inovasi. Jurnal Akuntansi, 1948-1964.

Sobandi, B. (2006). Desentralisasi dan Tuntutan Penataan. Kelembagaan Daerah Bandung.

Sundjaja, R. d. (2003). Manajemen Keuangan Satu (Vol. kelima). Jakarta: Literata Lintas Media.

Suryani, E. (2013). Infrastruktur Teknologi Informasi yang Menunjang Strategi Bisnis Pada Perusahaan Tambang: Studi Kasus PT XYZ. Journal ComTech, 574-581.

Tjahyawati A., D. (2012). Pengaruh Fleksibiltas Infrastruktur Teknologi Informasi Terhadap Kinerja Individual Pada Bank Rakyat Indonesia Cabang Jember. Jember: Repository Unej.

Widajanti, E. (2011). Peranan Infrastruktur Teknologi Informasi Bagi Perkembangan Usaha Kecil, dan Menengah di Indonesia. Jurnal Ekonomi dan Kewirausahaan, 1-9.

Widuri, J. d. (2013). Analisis Pengaruh Kinerja Teknologi Informasi Terhadap Kinerja Karyawan Administrasi Fakultas Ekonomi UNSOED. Sustainable Competitive Advantage (SCA). 